\title{
Normative study of theme identifiability: Instructions with and without explanation of the false memory effect
}

\author{
Maria Soledad Beato $^{1} \cdot$ Sara Cadavid ${ }^{1}$
}

Published online: 30 September 2015

(C) Psychonomic Society, Inc. 2015

\begin{abstract}
False-memory illusions have been widely studied using the Deese/Roediger-McDermott paradigm (DRM). In this paradigm, words semantically related to a single nonpresented critical word are studied. In a later memory test, critical words are often falsely recalled and recognized. The present normative study was conducted to measure the theme identifiability of 60 associative word lists in Spanish that include six words (e.g., stove, coat, blanket, scarf, chill, and bonnet) that are simultaneously associated with three critical words (e.g., HEAT, COLD, and WINTER; Beato \& Díez, Psicothema, 26, 457-463, 2011). Different levels of backward associative strength were used in the construction of the DRM lists. In addition, we used two types of instructions to obtain theme identifiability. In the without-explanation condition, traditional instructions were used, requesting participants to write the theme list. In the with-explanation condition, the false-memory effect and how the lists were built were explained, and an example of a DRM list and critical words was shown. Participants then had to discover the critical words. The results showed that all lists produced theme identifiability. Moreover, some lists had a higher theme identifiability rate (e.g., $61 \%$ for the critical words LOVE, BOYFRIEND, COUPLE) than others (e.g., $24 \%$ for CITY, PLACE, VILLAGE). After comparing the theme identifiabilities in the different conditions, the results indicated higher theme identifiability when the false-memory effect was explained than without such an explanation. Overall, these new normative data provide a useful tool for those
\end{abstract}

Maria Soledad Beato

msol@usal.es

1 University of Salamanca, Avenida de la Merced 109-131, E-37005 Salamanca, Spain experiments that, for example, aim to analyze the wide differences observed in false memory with DRM lists and the role of theme identifiability.

Keywords Theme identifiability $\cdot$ Deese/RoedigerMcDermott (DRM) paradigm · Backward associative strength (BAS)

Nowadays, it is commonly assumed that memory is a reconstruction of the past that is prone to various kinds of mistakes. Indeed, research examining memory errors has increased dramatically over the past years (see Gallo, 2006, 2010, for reviews). A type of memory error that has been extensively studied is the associative illusion of memory, using for this purpose the Deese/Roediger-McDermott (DRM) paradigm (Deese, 1959; Roediger \& McDermott, 1995). In this paradigm, participants study words that are semantically related to a single nonpresented word (critical word). Following the study phase, in a memory test, critical words are often falsely recalled and recognized. This paradigm has been widely employed because it produces robust false-memory effects across different experiments and conditions (e.g., Beato \& Arndt, 2014; Beato, Boldini, \& Cadavid, 2012; Del Prete, Mirandola, Konishi, Cornoldi, \& Ghetti, 2014; Pimentel \& Albuquerque, 2013). Similarly, much research has been conducted to explore the variables that increase or decrease false memories (e.g., Beato, Cadavid, Pulido, \& Pinho, 2013; Cadavid, Beato, \& Fernandez, 2012; Flegal \& Reuter-Lorenz, 2014; Graham, 2007; Unsworth \& Brewer, 2010; Zhu et al., 2010). Theme identifiability is one of them, as we will subsequently discuss.

Several theoretical approaches have been used to explain the false-memory illusion in the DRM paradigm. The two main contemporary theories, fuzzy-trace theory (Brainerd \& 
Reyna, 1990; Brainerd, Reyna, \& Ceci, 2008; Reyna \& Brainerd, 1995) and the activation-monitoring framework (Roediger, Balota, \& Watson, 2001; Roediger, Watson, McDermott, \& Gallo, 2001), converge in proposing two opposite processes that combine to elicit false memories: errorinflating processes and error-editing processes. The errorinflating processes would increase false memory and are available early in memory retrieval. On the other hand, the error-editing processes, when efficiently engaged, would allow one to reject the critical word as a studied word, decreasing false memory (Arndt \& Gould, 2006). Therefore, false memory occurs when, first, error-inflating processes occur and, subsequently, error-editing processes fail. Gallo (2004, 2006) focused on the decision process that underlies errorediting processes and, taking it into account, distinguished two classes of editing processes: diagnostic monitoring and disqualifying monitoring.

Diagnostic monitoring occurs when the critical word is not accompanied by an expected recollection, leading to the rejection of that item ("if I had studied that item, I would remember it; I do not recall it, so it must not have occurred"). In other words, in the DRM paradigm, diagnostic decisions are made by taking into account the quality of the mnemonic evidence related to the critical words. The absence of expected recollections for those items underlies their successful rejection.

Instead, disqualifying monitoring happens when participants do recall certain information about an item that is incompatible with the occurrence of the critical word, allowing them to reject the questionable item (i.e., critical word) as having occurred ("if I had studied that item, I would not be able to remember this other information; because I do recall information that excludes that item as a studied one, it must have not occurred"). In this type of monitoring, the decision is made on the basis of the recollection of collateral information (Gallo, 2006).

One of the strategies employed in disqualifying monitoring is the identify-to-reject strategy (e.g., Carneiro et al., 2012). This strategy requires that, first, participants are able to detect the associative nature of the lists, noticing that all of the words in a list are related to a common theme. Second, they must identify a word that connects all of the listed items (theme word list or critical word). Third, participants have to realize that this word is not included in the list, labeling it as a nonpresented word. Finally, when the identified word (critical word) is presented in the recognition test, it is necessary to recall their earlier discovery that this was a nonpresented word, so they correctly reject the critical word as studied and avoid false recognition. Similarly, in a free recall task, the critical word is kept in mind in order not to falsely recall it (Gallo, 2006).

In the DRM paradigm context, it has been confirmed that participants frequently resort to an identify-to-reject strategy to disqualify the critical word, reducing the occurrence of false memories (e.g., Carneiro, Fernandez, \& Dias, 2009; Gallo, Roberts, \& Seamon, 1997).

Moreover, sometimes the identify-to-reject strategy is given to participants for the purpose of decreasing false-memory rates. Thus, in warning studies conducted with DRM lists, participants receive specific instructions about the falsememory effect, encouraging them to identify the nonpresented critical word that was related to all of the list words. Several studies have shown that this type of instructions dramatically decreased both false recall (e.g., Peters et al., 2008; Watson, Bunting, Poole, \& Conway, 2005; Watson, McDermott, \& Balota, 2004) and false recognition (e.g., Gallo et al., 1997; Gallo, Roediger, \& McDermott, 2001; McCabe \& Smith, 2002; McDermott \& Roediger, 1998; Multhaup \& Conner, 2002; Neuschatz, Benoit, \& Payne, 2003; Peters et al., 2008; Westerberg \& Marsolek, 2006).

Therefore, identification of the theme of the list (i.e., identification of the critical word) seems to be an essential factor when considering the error-editing processes. That is the reason why theme identifiability (identification of the critical word of each list) represents one of the most promising research fields within the domain of false memory. Getting to know how identifiable a critical word is after all of its associated items are presented constitutes an optimal way to explore how editing processes work when participants are shown a DRM list in false-memory experiments. More specifically, these editing processes are particularly efficient in lists with highly identifiable critical words, for which false-memory rates are lower (e.g., Carneiro et al., 2009; Carneiro et al., 2012; Carneiro \& Fernandez, 2013; but see also Neuschatz et al., 2003, where false-memory rates decreased only when there was prior warning of the false-memory effect). To reach these conclusions, Carneiro et al. (2009) conducted a study in which they obtained theme identifiability indexes for onecritical-word lists while they explored false-memory production in both children and adults. They found that the level of identifiability of the critical word was inversely related to false recognition only among the adult participants. According to Carneiro et al. (2009), this finding suggests that adults are more likely than children to engage in an identify-to-reject strategy spontaneously. As a consequence, identifiability tasks could provide valuable data for how error-editing processes work in the human mind throughout a lifespan. In a more recent study, Carneiro et al. (2012) replicated the identifiability effect (lower false memory rates for higher identifiable critical words), in both visual and auditory conditions. Moreover, these authors proved that speeded presentation rates in the study phase and a speeded response condition at test interfere with the startup of the identify-to-reject strategy, eliminating the identifiability effect or even reversing the pattern (i.e., higher false-memory rates for more identifiable critical words). These interesting findings show the existing 
intricate relationship between error-editing processes and false memory, as well as the main role that identifiability tasks could play in unraveling the mechanisms involved in associative illusions of memory.

DRM lists are constructed on the basis of free association norms. In free association normative studies, a series of words (the cue) are presented, and participants are asked to provide the first word that comes to mind (the target). With this procedure, researchers establish a cue-target relationship and calculate the proportion of participants who elicit a determined target in response to a particular cue. This proportion is considered to be an index of the associative strength between the two words (McEvoy, Nelson, \& Komatsu, 1999). In the DRM paradigm, two types of lists are generally constructed with free association norms. Forward associative strength (FAS) lists include a cue word as a critical word and several targets (i.e., words produced by cue word) as studied words. In backward associative strength (BAS) lists, one particular target is considered the critical word and several cue words that produced that target are included as studied words.

Initially, the DRM lists used in the study of false memories were FAS lists (e.g., Boldini, Beato, Cadavid, 2013; Gallo \& Roediger, 2002; Roediger \& McDermott, 1995; Stadler, Roediger, \& McDermott, 1999), characterized by the fact that the critical words produced the studied words in free association tasks. However, subsequent research suggested that BAS (the associative strength from the studied items to the critical words) is the best predictor of false memories (e.g., Deese, 1959; Howe, Wimmer, \& Blease, 2009; McEvoy et al., 1999; Robinson \& Roediger, 1997; Roediger, Balota, \& Watson, 2001). Consequently, in a recent DRM false-memory normative study conducted by Beato and Díez (2011), lists were constructed using BAS values, in line with other researchers who have pointed out the importance of employing BAS lists (e.g., Carneiro, Ramos, Costa, Garcia-Marques, \& Albuquerque, 2011).

Furthermore, Beato and Díez's (2011) lists had one characteristic that made them especially innovative: Specifically, the BAS DRM lists included six associated words simultaneously related to three critical words, instead of including a single critical word per list. There are several reasons to believe that three-critical-word lists are an improvement over one-criticalword lists. First, lists with multiple critical words could hinder successful triggering of spontaneous error-editing processes. Thus, in three-critical-word DRM lists, it would be more difficult to (a)realize the associative structure of the list, (b) spontaneously identify all of the critical words, and (c) control the false-memory effect. Second, assuming that two opposite processes are involved in false memories (errorediting and error-inflating processes), discouraging the engagement of the error-editing processes would allow for a more precise exploration of the error-inflating processes. Since spontaneous error-editing processes are not as easy to engage in multiple-critical-word lists, these materials allow for a better evaluation of how associative variables have an impact on memory error-inflating processes. Third, lists with three critical words contributed to satisfy a compelling methodological need in event-related potential (ERP) DRM research. Commonly, these studies seek to examine the similarities and differences between true and false memories (e.g., Curran, Schacter, Johnson, \& Spinks, 2001). Whereas the ERPs for true memories are obtained from averaging trials for studied-item hits, the ERPs for false memories are obtained from averaging critical-word false alarm trials. In classical DRM/ERP studies, the lists include only one critical word and 15 studied words, and, consequently, the number of averageable critical-word trials is significantly lower than the number of true-memory trials. Since the signal-to-noise $(\mathrm{S} / \mathrm{N})$ ratio (a measure of the quality of the signal) increases with the number of trials included in the average, the small number of critical trials creates a methodological challenge to obtain reliable ERP waveforms for false memories. Furthermore, the disparity between the $\mathrm{S} / \mathrm{N}$ ratios found in true and false memory ERP waveforms make comparisons difficult to interpret (Luck, 2005). Alternative solutions to this problem have been proposed (Curran et al., 2001; Wiese \& Daum, 2006), but they have failed to maintain the DRM associative structure in the lists (see Beato \& Díez, 2011, for a discussion of this alternative). Thus, three-critical-word DRM lists, the materials employed in this study, seem to constitute adequate materials to study (1)how error-editing processes are involved in false memories, (2) how error-inflating processes have an impact on false memory, and (3)false-memory ERP waveforms.

In traditional one-critical-word DRM lists, the theme identifiability is the proportion of participants who identify the critical word in each list (e.g., Carneiro \& Fernandez, 2013; Carneiro et al., 2009; Carneiro et al., 2011; Carneiro et al., 2012). In the present normative study, our goal was to investigate the theme identifiability for three-critical-word lists. Accordingly, we obtained theme identifiability for each one of the three critical words included in each list (hereafter referred to as the theme identifiability per critical word), consistent with the methodology of one-critical-word DRM research (i.e., the proportion of participants able to identify each critical word was computed). Also, for purposes of comparison with traditional DRM lists, each of which has one value for theme identifiability, we averaged the identifiability values of the three critical words within each list to obtain the theme identifiability per list.

In the present normative study, we obtained the theme identifiability from the Spanish lists previously published by Beato and Díez (2011). Two types of instructions were used for this purpose. On the one hand, we aimed to know the theme identifiability when we employed the traditional instructions previously used in other studies (i.e., without-explanation instructions; e.g., Carneiro et al., 2009). On the other, 
we wanted to obtain theme identifiability values when participants were made aware of how the lists were built and of the false-memory effect (i.e., with-explanation instructions). In the latter case, they were explicitly encouraged to search for the critical word. The first type of instructions made it possible to compare the normative data obtained in this study with those obtained in previous studies employing both FAS (e.g., Carneiro et al., 2009) and BAS (Carneiro et al., 2011) lists with only one critical word per list. Meanwhile, the second type of instructions provided new theme identifiability normative data, this time with warning instructions.

In summary, in this study, for the first time, we obtained theme identifiability norms in Spanish. Also for the first time, theme identifiability values were obtained in associative lists with three critical words per list. Furthermore, it was also the first time that theme identifiability values were obtained by using a warning instruction. In future research, these new data can help us understand the role of theme identifiability in the formation of false memories.

\section{Method}

\section{Participants}

Four hundred seven undergraduate students participated in this study. All of them were native Spanish speakers. Their ages ranged from 18 to 41 years $(M=20.09, S D=2.87)$, and $80.59 \%$ were women. The participants volunteered, received course credit for their participation, and signed written informed consent.

\section{Materials}

Sixty associative lists composed of six associates with BAS to the same three critical words were employed in this study. The lists were obtained from a previous Spanish DRM normative study (Beato \& Díez, 2011; see the Appendix for all of the stimuli and their approximate English translations). For the application of the study, the lists were distributed in four groups of 15 lists, so that no associate or critical words were repeated within each set.

The associates within each list were arranged in decreasing order of their associative relationship to the critical words (i.e., BAS) and were digitalized with a male voice. Because the present lists included three critical words, BAS values were obtained (1)for each critical word and (2) for each DRM list. The BAS values for each critical lure word were determined by the sum of the associative strengths of its six associated words (range $=0.20-2.34, M=0.83, S D=0.47$ ). Similarly, the associative strength value of each list (i.e., the BAS list strength) was calculated as the sum of the BAS values for the three critical words (range $=1.35-4.00, M=2.50, S D=$ 0.52; Beato \& Díez, 2011).

The materials used in this study covered a broad spectrum of the possible range of BAS values in the DRM paradigm. The highest BAS list strength value (4.00) represents the maximum that could be obtained in DRM lists with three critical words. This value is considerably higher than the lowest BAS list strength (1.35) presented in this study. This lower end of the spectrum is similar to that employed in previous DRM experiments conducted with both one (Knott, Dewhurst, \& Howe, 2012) and three (Cadavid et al., 2012) critical words.

For the theme identifiability test, a response booklet was created, including a first page that collected information about the participant. As in previous studies (Carneiro et al., 2009), on each of the remaining pages were spaces to write three possible response words or themes per list (subsequently considered as the first, second, and third possible responses).

The normative study of theme identifiability in the associative word lists was conducted employing two different types of instructions. Specifically, all participants listened to the sixword lists, and approximately half of them were instructed to write the words that they thought best described the themes of each list (e.g., Carneiro et al., 2009; the without-explanation condition, hereafter). In the without-explanation condition, the instructions were:

You are going to listen to six-word lists. Your task consists of finding the words that you think best define the topics of the list. In other words, you must discover the possible themes of each list and write them down. To fill out the booklet, first you must listen carefully to all of the words on the list. Only when the presentation of the list is finished can you write down the three words you think best describe the themes of the list. I will let you know when the time to answer is finished, and when a new list starts.

The rest of the participants received a brief explanation about false-memory effect and how the lists had been built (the with-explanation condition, hereafter). In this condition, the instructions were as follows:

You are going to listen to six-word lists. These six words are simultaneously related to three other words that you are not going to hear. Your task consists of discovering which are those three related but unpresented words. In order to do so, you must take into account that the three words are related to every single word that was actually presented. For example, imagine you listen to the list premio [prize], ganar [win], copa [cup], triunfo [triumph], ganador [winner], and campeón [champion]. All these words are associated with PODIO [PODIUM], TROFEO [TROPHY], and VENCEDOR 
[VICTORIOUS]. These three last words would be the words that you must determine and write down in the booklet. This type of list has been built to study memory distortions, more specifically false memory. People often make the mistake of considering the related but unpresented words as if they were actually studied. For example, when participants study the previous list, they often falsely recall or recognize PODIO, TROFEO, and VENCEDOR as studied words. To fill out the booklet, first you must listen carefully to all the words of the list. Only when the presentation of the list is finished can you write down the three words you think are related to all of the six words on the list. I will let you know when the time to answer is finished, and when a new list starts.

In sum, in the with-explanation condition, as opposed to the without-explanation condition, participants were informed about the associative structure of the materials and how that type of list has been used to induce memory distortions. In addition, participants assigned to this condition were shown a sample DRM list with its related critical words, serving as an example of the types of words they were expected to produce. Then, they were instructed to figure out what the three critical words of each list were and to write them down. This manipulation aimed to trigger more elaborate and DRM-related strategies to identify the critical words.

\section{Procedure}

Participants were run in group sessions. After signing the consent form, they were informed that the purpose of the study was to analyze the relationships between different words. Then they received the assigned instructions for each condition - with explanation or without explanation, with the characteristics mentioned above. Subsequently, they listened to the word lists through the speakers. The order of presentation of the lists was random, and six different orders were created. The words were presented by a male voice at a rate of one word every $2 \mathrm{~s}$. Following the presentation of each list, participants would be asked to write the three possible answers per list for approximately $30 \mathrm{~s}$. The same procedure was repeated until the end of the 15 session lists.

\section{Results and discussion}

The Appendix includes the 60 six-word lists with their three critical words apiece, the BAS values per critical word, and the identifiability for each critical word in the without-explanation and with-explanation conditions.
Intrusion rates and numbers of participants are specified per list.

Every time a participant was able to identify a critical word within each list, it was considered a "hit," regardless of whether the word was written in first, second, or third place in the booklet. Therefore, each participant could have zero, one, two, or three hits per list. Every response that did not correspond to a critical word was considered an "intrusion." There were very few blank responses in both the with- and without-explanation conditions (.03 and .06 , respectively).

Therefore, theme identifiability was obtained for each of the 180 critical words (theme identifiability per critical word). Furthermore, the theme identifiability per critical word was averaged across the three words included in each of the lists, obtaining 60 values of theme identifiability per list. In addition, the intrusion rate was computed for each list.

\section{Theme identifiability without explanation of the false-memory effect}

Theme identifiability per list Although all lists produced theme identifiability, a detailed analysis showed wide differences in the theme identifiabilities for each list (the mean percentages of the three critical words; range $=24 \%-61 \%, M=41.00, S D=25.20)$. Some lists yielded lower levels of theme identifiability (e.g., $24 \%$ for the list CIUDAD [city], LUGAR [place], PUEBLO [village]: villa [town], municipio [municipality], localidad [locality], comarca [district], localización [location], región [region]) than did other lists (e.g., $61 \%$ for both AMOR [love], NOVIO [boyfriend], PAREJA [couple]: pretendiente [suitor], cariño [fondness], relación [relationship], enamorado [in love], besar [to kiss], caricia [caress]; and CALOR [heat], FRÍO [cold], INVIERNO [winter]: estufa [stove], abrigo [coat], manta [blanket], bufanda [scarf], escalofrio [chill], gorro [bonnet]).

Theme identifiability per critical word The theme identifiability for individual critical words was also highly variable (range $=0 \%-96 \%, M=41.00, S D=$ 27.00). More precisely, none of the participants produced as a possible theme the critical words FRESA [strawberry] and ROSA [rose], whereas the critical word FIESTA [party] showed the highest theme identifiability (96\%).

These results are consistent with previous studies (e.g., Carneiro et al., 2009; Carneiro et al., 2011) that displayed high variability in theme identifiability values. For example, Carneiro et al. (2009), employing onecritical-word FAS lists, obtained identifiability rates that ranged from $1 \%$ to $77 \%(M=36.42)$. Still greater was 
the variability found by Carneiro et al. (2011) using BAS lists (from $1 \%$ to $92.9 \%, M=42.20$ ).

Theme identifiability of any of the three critical words, among the first, second, or third possible responses Hit responses to any of the critical words written in the first, second, or third possible response spaces differed considerably, $F(2,759)=813.58, p<.001(p<.001$ in all post-hoc comparisons). Specifically, $55.5 \%$ of hits occurred in the first possible response, $30 \%$ appeared in the second possible response, and, finally, $14.5 \%$ of correct theme identifications happened in the third possible response. As we can see, most of the theme identifiability happened in the first possible response (over $50 \%$ of the time), but the other two possible responses also provided important data (almost $50 \%$ of responses).

\section{Theme identifiability with explanation of the false-memory effect}

Theme identifiability per list When participants received instructions with an explanation of the false-memory effect, we also found that all lists produced theme identifiability. Similarly, analysis of the data indicated high variability in the percentages of theme identifiability, with values ranging from $19 \%$ (FÚTBOL [football], JUEGO [game], PELOTA [tennis ball]: balón [ball], deportes [sports], béisbol [baseball], baloncesto [basketball], bola [pellet], tenis [tennis]) to $68 \%$ (AIRE [air], CIELO [sky], VOLAR [to fly]: globo [balloon], cometa [kite], avión [plane], helicóptero [helicopter], pájaro [bird], águila [eagle] $)(M=46.30, S D$ $=11.50$ ).

Theme identifiability per critical word The theme identifiability analysis for critical words also showed wide variability. Specifically, the critical words CURA [clergyman], CHOCOLATE [chocolate], CATARRO [catarrh], MONJE [monk], ROSA [rose], and TEMOR [awe] were never identified as themes, whereas the critical word FIESTA [party] showed the highest theme identifiability $(100 \%)$. On the whole, the mean theme identifiability for the 60 three-critical-word lists was $46.30 \%(S D=28.50)$. This value was considerably higher than those obtained in previous studies employing traditional instructions with FAS lists (e.g., Carneiro et al., 2009: $36 \%$ ).

Theme identifiability of any of the three critical words, among the first, second, or third possible responses As in the data presented above, hit responses to any of the critical words in the first, second, or third possible response spaces differed considerably, $F(2,456)=536.88, p<.001(p<.001$ in all post-hoc comparisons). Specifically, the first possible response provided the highest rate of hits (53.2\%), followed by the second $(31.2 \%)$ and third $(15.6 \%)$ possible responses.

\section{Analysis of potential predictor variables of theme identifiability}

As in previous studies, a high amount of variability was found in theme identifiability. With the aim of better understanding the nature of this variability, a multiple regression analysis was conducted on the theme identifiability data for each of the conditions. For each analysis, five variables (age of acquisition, BAS, FAS, word length, and written frequency) based on the characteristics of the critical words were entered simultaneously into the equation to predict theme identifiability. These variables have been explored in previous studies interested in variability phenomena in DRM lists (e.g., Carneiro et al., 2009; Roediger, Watson, et al., 2001). Both the age-of-acquisition and written frequency indexes were obtained from Alonso, Fernandez, and Díez's (2015) study, whereas the BAS and FAS values were obtained from Fernandez, Díez, and Alonso's (2009) database.

The regression analysis conducted on the theme identifiability data collected in the with-explanation condition revealed that the total model explained $33 \%$ of the variance, $F(5,157)=15.053, p<.001$, adjusted $R^{2}$ $=.30$. As is shown in Table 1, the results indicated that BAS, word length, and written frequency were significantly related to theme identifiability, $p \mathrm{~s}<.001$. In the with-explanation condition, BAS appears to be the strongest predictor of theme identifiability, $\beta=.530$, $s r=.512, t=7.505$.

Another multiple regression analysis was run, including the same five variables (age of acquisition, BAS, FAS, word length, and written frequency) and with theme identifiability in the without-explanation condition as the dependent variable. In this case, the total model explained $35 \%$ of the variance, $F(5,157)=$ $15.928, p<.001$, adjusted $R^{2}=.32$. Again, only BAS, word length, and written frequency were significantly related to theme identifiability in the withoutexplanation condition, $p s<.001$ (see Table 1 for the regression coefficients and standard errors). As in the with-explanation condition, BAS was the strongest predictor of theme identifiability in the without-explanation condition, $\beta=.555, s r=.512, t=7.927$. 
Table 1 Summary of multiple regression analyses on theme identifiability (with- and without-explanation conditions), in which age of acquisition, backward associative strength (BAS), forward associative strength (FAS), word length, and written frequency were employed as predictors

\begin{tabular}{|c|c|c|c|c|c|c|c|c|c|c|}
\hline \multirow[t]{2}{*}{ Variable } & \multicolumn{5}{|c|}{ With-Explanation Condition } & \multicolumn{5}{|c|}{ Without-Explanation Condition } \\
\hline & $\mathrm{B}$ & $S E_{\mathrm{B}}$ & $\beta$ & $s r$ & $t$ Value & $\mathrm{B}$ & $S E_{\mathrm{B}}$ & $\beta$ & $s r$ & $t$ Value \\
\hline Age of acquisition & -.013 & .015 & -.065 & -.161 & -0.859 & .003 & .013 & .018 & -.096 & 0.236 \\
\hline BAS & .622 & .083 & $.530^{*}$ & .512 & 7.505 & .608 & .077 & $.555^{*}$ & .512 & 7.927 \\
\hline FAS & -.009 & .045 & -.016 & -.046 & -0.210 & -.027 & .041 & -.048 & -.064 & -0.650 \\
\hline Word length & .507 & .182 & $.205^{*}$ & .010 & 2.782 & .460 & .169 & $.199^{*}$ & .028 & 2.729 \\
\hline Written frequency & .101 & .040 & $.188^{*}$ & .209 & 2.553 & .100 & .037 & $.200^{*}$ & .227 & 2.744 \\
\hline
\end{tabular}

$\mathrm{B}=$ unstandardized regression coefficient, $S E_{\mathrm{B}}=$ standard error of the coefficient, $\beta=$ standardized coefficient, $s r=$ semipartial correlation. ${ }^{*} p<.001$

\section{Relationship between BAS, intrusion rate, and theme identifiability with and without explanation}

In order to determine whether there was a relationship between BAS and theme identifiability with and without explanation of the false-memory effect, two correlational analyses were conducted.

Theme identifiability per critical word The first correlational analysis evaluated the relationship between BAS and theme identifiability with and without explanation per critical word. The analysis included 180 values of BAS per critical word, 180 values of theme identifiability per critical word in the with-explanation condition, and 180 values of theme identifiability in the without-explanation condition. This analysis showed significant correlations between BAS and theme identifiability both with and without explanation, $r=.52, p<$ $.001 ; r=.54, p<.001$, respectively. Furthermore, we also found a significant positive correlation between theme identifiability in the with- and without-explanation conditions per critical word, $r=.91, p<.001$.

Theme identifiability per list In the second correlational analysis, we included BAS list strength, theme identifiability per list (in both the with- and without-explanation conditions), and intrusions per list in both conditions (words generated that were not critical words). This analysis included 60 values of BAS per list, 60 values of theme identifiability per list in the with-explanation condition, 60 values of theme identifiability in the without-explanation condition, 60 values of intrusions per list in the with-explanation condition, and 60 values of intrusions per list in the without-explanation condition. Again, we obtained significant correlations between BAS and theme identifiability with explanation, $r=.33, p=.011$, and between BAS and theme identifiability without explanation, $r=.44, p$ $<.001$. Also, we found a significant correlation between theme identifiability per list in the with- and withoutexplanation conditions, $r=.80, p<.001$. Furthermore, we found a significant negative correlation between BAS list strength and intrusions obtained both with and without explanation of the false-memory effect, $r=-.31, p=.015 ; r=-.37$, $p=.004$, respectively. When we analyzed the relationship between theme identifiability and intrusions in the withand without-explanation conditions, as expected, we found significant negative correlations between theme identifiability and intrusions with explanation, $r=$ $-.97, p<.001$, and between theme identifiability and intrusions without explanation, $r=-.91, p<.001$. A significant correlation between intrusions with and without explanation also emerged, $r=.73, p<.001$.

These analyses suggest that, independently of the type of instructions (with or without explanation), the higher the theme identifiability, the higher the BAS, and the higher the theme identifiability, the lower the intrusions. Similar results had been found in previous studies with classical instructions (without explanation) and one-critical-word lists (e.g., Carneiro et al., 2011).

\section{Theme identifiability and intrusion rates between conditions}

To confirm that the new instructions used to obtain theme identifiability provided relevant information to the field, we further analyzed whether to include an explanation of the false-memory effect significantly modified theme identifiability. The independent-samples $t$ test confirmed that participants showed higher theme identifiability when we explained the false-memory effect $(M=46, S D=9.8)$ than without such explanation $(M=41, S D=9.2)$, a statistically significant difference of $5.1 \%$ (95\% confidence interval $[\mathrm{CI}], 3.2$ to 7.0$)$, $t(405)=5.327, p<.001, d=0.545$. 
Another independent-samples $t$ test was conducted to explore whether there were differences in the rates of intrusions provided by participants assigned to the withexplanation condition $(M=51.1, S D=9.6)$ and the without-explanation condition $(M=52.8, S D=11.7)$. The two types of instructions did not significantly affect the intrusions produced, showing a difference of -1.7 $(95 \% \mathrm{CI},-3.93$ to 0.46$), t(405)=-1.553, p=.061$, $d=-0.15$.

\section{Conclusions}

The aim of this normative study was to empirically obtain theme identifiability values for 60 lists of six words in Spanish (e.g., escena [scene], estreno [premiere], escenario [stage], trama [plot], actor [actor], and ficción [fiction]) that were simultaneously associated with three critical words (e.g., CINE [cinema], PELÍCULA [film], and TEATRO [theatre]). Previous studies had found identifiability values for other languages, such as English (Neuschatz et al., 2003) or Portuguese (e.g., Carneiro et al., 2009); however, to our knowledge, the present study represents the first attempt to develop theme identifiability norms in Spanish. These norms could be useful in selecting DRM materials for experiments conducted with Spanish speakers, both monolingual and bilingual. Moreover, for the first time, we obtained theme identifiability values in associative word lists that were built by taking into account BAS and including multiple critical words. Furthermore, another important contribution of this work was that theme identifiability values were obtained using two different types of instructions. On the one hand, instructions like the ones previously used in other studies (i.e., instructions without explanation) were employed. On the other hand, theme identifiability was also obtained with instructions explaining how the lists were built and the false-memory effect (i.e., instructions with explanation). The first type of instructions made it possible to compare our normative data with those obtained in previous normative studies that had employed this type of instructions (e.g., Carneiro et al., 2009; Carneiro et al., 2011), whereas the second type of instructions provided, for the first time in the literature, theme identifiability normative data when participants were aware of the existence of critical words related to the associative lists. The latter type of data is particularly interesting for studies designed to examine the error-editing processes in false memory, and more specifically, disqualifying monitoring that employs the identify-to-reject strategy.
The results confirmed that it is possible to obtain theme identifiability, although it should also be noted that the lists showed wide differences in theme identifiability (without explanation, range $=24 \%-61 \%$; with explanation, range $=$ $19 \%-68 \%$ ). A high variability was also found when considering theme identifiability per critical word (without explanation, range $=0 \%-96 \%$; with explanation, range $=0 \%-$ $100 \%$ ). This fairly wide variability was also observed in previous theme identifiability studies, all of which had one critical word per list (e.g., Carneiro et al., 2009, range from $1 \%$ to $77 \%$; Carneiro et al., 2011, range from $1 \%$ to $92.9 \%$ ).

To better understand why this variability occurs, separate multiple regression analyses were conducted on the theme identifiability data in the with- and withoutexplanation conditions. The results indicated similar patterns of results in both conditions. Age of acquisition and FAS did not predict theme identifiability in any conditions, but BAS, word length, and written frequency were significantly related to theme identifiability in both the with- and without-explanation conditions. Specifically, BAS was the strongest predictor of theme identifiability.

In addition, although in both conditions the potential predicting variables showed similar patterns of results, we observed higher theme identifiability in the withexplanation than in the without-explanation condition. Therefore, this disparity in theme identifiability does not seem to be a consequence of differential effects of the critical-word characteristics included in this study (i.e., age of acquisition, BAS, FAS, word length, and written frequency). Instead, the type of instructions seems to engage different error-editing processes in both conditions. Specifically, the instructions used in the with-explanation condition seem to be appropriate to boost the performance in deliberated error-editing processes, obtaining a higher theme identifiability. Thus, we were able to confirm that the new instructions, used for the very first time to obtain theme identifiability, provided relevant information to the field.

In summary, the increased identifiability when the false-memory effect is explained suggests that this is an appropriate way to obtain identifiability indexes and that it can be used in future investigations. Specifically, these new theme identifiability values will be very useful to understand the effect that certain variables (e.g., warnings) might have on false memories, opening a whole new range of experimental possibilities. Moreover, the results of the present normative study can be employed in future research aimed at examining the relationship between identifiability and false memories and, more specifically, at analyzing to what extent the identify-to-reject strategy is decisive in the production of accurate memories. 


\section{Appendix}

Table 2 The 60 DRM lists in Spanish, with their approximate English translations in parentheses

\begin{tabular}{|c|c|c|c|c|c|c|c|c|c|c|c|}
\hline & \multirow{3}{*}{$\begin{array}{l}\text { CRITICAL } 1 \text { / CRITICAL } 2 \text { / CRITICAL 3: } \\
\text { Six Associated Words (approximated English } \\
\text { translation) }\end{array}$} & \multicolumn{5}{|c|}{$\begin{array}{l}\text { Without-Explanation condition } \\
n=153\end{array}$} & \multicolumn{5}{|c|}{$\begin{array}{l}\text { With-Explanation condition } \\
n=254\end{array}$} \\
\hline & & \multirow[t]{2}{*}{$n$} & \multicolumn{3}{|c|}{ ID (BAS) } & \multirow[t]{2}{*}{ Intrusions } & \multirow[t]{2}{*}{$n$} & \multicolumn{3}{|c|}{ ID (BAS) } & \multirow[t]{2}{*}{ Intrusions } \\
\hline & & & Crit 1 & Crit 2 & Crit 3 & & & Crit 1 & Crit 2 & Crit 3 & \\
\hline List 01 & $\begin{array}{l}\text { AIRE / CIELO / VOLAR: globo, cometa, avión, } \\
\text { helicóptero, pájaro, águila } \\
\text { (AIR / SKY / TO FLY: balloon, kite, plane, } \\
\text { helicopter, bird, eagle) }\end{array}$ & 52 & $\begin{array}{l}.346 \\
(0.535)\end{array}$ & $\begin{array}{l}.442 \\
(0.335)\end{array}$ & $\begin{array}{l}.654 \\
(1.004)\end{array}$ & .397 & 40 & $\begin{array}{l}.575 \\
(0.535)\end{array}$ & $\begin{array}{l}.650 \\
(0.335)\end{array}$ & $\begin{array}{l}.800 \\
(1.004)\end{array}$ & .317 \\
\hline List 02 & $\begin{array}{l}\text { AMOR / NOVIO / PAREJA: pretendiente, cariño, } \\
\text { relación, enamorado, besar, caricia } \\
\text { (LOVE / BOYFRIEND / COUPLE: suitor, } \\
\text { fondness, relationship, in love, to kiss, caress) }\end{array}$ & 52 & $\begin{array}{l}.808 \\
(1.495)\end{array}$ & $\begin{array}{l}.269 \\
(0.585)\end{array}$ & $\begin{array}{l}.750 \\
(0.240)\end{array}$ & .314 & 40 & $\begin{array}{l}.800 \\
(1.495)\end{array}$ & $\begin{array}{l}.475 \\
(0.585)\end{array}$ & $\begin{array}{l}.475 \\
(0.240)\end{array}$ & .392 \\
\hline List 03 & $\begin{array}{l}\text { ARMA / GUERRA / PISTOLA: metralleta, balas, } \\
\text { munición, fusil, rifle, disparo } \\
\text { (WEAPON / WAR / PISTOL: machine gun, bullets, } \\
\text { ammunition, handgun, rifle, shot) }\end{array}$ & 52 & $\begin{array}{l}.558 \\
(0.835)\end{array}$ & $\begin{array}{l}.904 \\
(0.875)\end{array}$ & $\begin{array}{l}.019 \\
(0.965)\end{array}$ & .468 & 40 & $\begin{array}{l}.650 \\
(0.835)\end{array}$ & $\begin{array}{l}.575 \\
(0.875)\end{array}$ & $\begin{array}{l}.075 \\
(0.965)\end{array}$ & .567 \\
\hline List 04 & $\begin{array}{l}\text { ALCOHOL / CERVEZA / VINO: taberna, litro, } \\
\text { borracho, botella, beber, borrachera } \\
\text { (ALCOHOL / BEER / WINE: tavern, liter, drunk, } \\
\text { bottle, to drink, drunkenness) }\end{array}$ & 52 & $\begin{array}{l}.808 \\
(0.793)\end{array}$ & $\begin{array}{l}.077 \\
(0.490)\end{array}$ & $\begin{array}{l}.058 \\
(0.466)\end{array}$ & .532 & 40 & $\begin{array}{l}.750 \\
(0.793)\end{array}$ & $\begin{array}{l}.025 \\
(0.490)\end{array}$ & $\begin{array}{l}.050 \\
(0.466)\end{array}$ & .692 \\
\hline List 05 & $\begin{array}{l}\text { IGLESIA / BODA / CURA: párroco, ceremonia, } \\
\text { sacerdote, capellán, capilla, casar } \\
\text { (CHURCH / WEDDING / CLERGYMAN: parish } \\
\text { priest, ceremony, priest, chaplain, chapel, to } \\
\text { marry) }\end{array}$ & 52 & $\begin{array}{l}.827 \\
(1.262)\end{array}$ & $\begin{array}{l}.385 \\
(0.730)\end{array}$ & $\begin{array}{l}.019 \\
(1.064)\end{array}$ & .513 & 40 & $\begin{array}{l}.675 \\
(1.262)\end{array}$ & $\begin{array}{l}.400 \\
(0.730)\end{array}$ & $\begin{array}{l}.000 \\
(1.064)\end{array}$ & .642 \\
\hline List 06 & $\begin{array}{l}\text { CAMA / DORMIR / NOCHE: mesilla, descansar, } \\
\text { sueño, camisón, descanso, soñar } \\
\text { (BED / TO SLEEP / NIGHT: bedside table, to rest, } \\
\text { dream, nightdress, rest, to dream) }\end{array}$ & 52 & $\begin{array}{l}.404 \\
(0.610)\end{array}$ & $\begin{array}{l}.712 \\
(1.320)\end{array}$ & $\begin{array}{l}.481 \\
(0.710)\end{array}$ & .346 & 40 & $\begin{array}{l}.650 \\
(0.610)\end{array}$ & $\begin{array}{l}.825 \\
(1.320)\end{array}$ & $\begin{array}{l}.300 \\
(0.710)\end{array}$ & .408 \\
\hline List 07 & $\begin{array}{l}\text { CASA / CIUDAD / PUEBLO: rural, urbe, villa, } \\
\text { urbana, municipio, habitante } \\
\text { (HOME / CITY / VILLAGE: rural, metropolis, } \\
\text { town, urban, municipality, inhabitant) }\end{array}$ & 52 & $\begin{array}{l}.077 \\
(0.340)\end{array}$ & $\begin{array}{l}.346 \\
(1.169)\end{array}$ & $\begin{array}{l}.308 \\
(1.188)\end{array}$ & .699 & 40 & $\begin{array}{l}.125 \\
(0.340)\end{array}$ & $\begin{array}{l}.550 \\
(1.169)\end{array}$ & $\begin{array}{l}.425 \\
(1.188)\end{array}$ & .592 \\
\hline List 08 & $\begin{array}{l}\text { DINERO / SUELDO / TRABAJO: monedero, } \\
\text { cobrar, salario, empleo, jornal, paga } \\
\text { (MONEY / WAGE / WORK: purse, to charge, } \\
\text { salary, employment, day's pay, pay) }\end{array}$ & 52 & $\begin{array}{l}.731 \\
(1.943)\end{array}$ & $\begin{array}{l}.154 \\
(0.338)\end{array}$ & $\begin{array}{l}.615 \\
(0.733)\end{array}$ & .333 & 40 & $\begin{array}{l}.800 \\
(1.943)\end{array}$ & $\begin{array}{l}.300 \\
(0.338)\end{array}$ & $\begin{array}{l}.600 \\
(0.733)\end{array}$ & .433 \\
\hline List 09 & $\begin{array}{l}\text { CHOCOLATE / DULCE / FRESA: batido, sabor, } \\
\text { caramelo, pastel, mermelada, tarta } \\
\text { (CHOCOLATE / SWEET / STRAWBERRY: milk } \\
\text { shake, flavor, candy, pie, jam, cake) }\end{array}$ & 52 & $\begin{array}{l}.019 \\
(0.557)\end{array}$ & $\begin{array}{l}.865 \\
(1.201)\end{array}$ & $\begin{array}{l}.000 \\
(1.010)\end{array}$ & .635 & 40 & $\begin{array}{l}.000 \\
(0.557)\end{array}$ & $\begin{array}{l}.925 \\
(1.201)\end{array}$ & $\begin{array}{l}.025 \\
(1.010)\end{array}$ & .658 \\
\hline List 10 & $\begin{array}{l}\text { CATARRO / ENFERMEDAD / GRIPE: contagio, } \\
\text { virus, constipado, tos, resfriado, estornudo } \\
\text { (CATARRH / DISEASE / FLU: contagion, virus, to } \\
\text { have a cold, cough, cold, sneeze) }\end{array}$ & 52 & $\begin{array}{l}.173 \\
(0.465)\end{array}$ & $\begin{array}{l}.865 \\
(0.785)\end{array}$ & $\begin{array}{l}.269 \\
(1.060)\end{array}$ & .442 & 40 & $\begin{array}{l}.000 \\
(0.465)\end{array}$ & $\begin{array}{l}.825 \\
(0.785)\end{array}$ & $\begin{array}{l}.400 \\
(1.060)\end{array}$ & .583 \\
\hline List 11 & $\begin{array}{l}\text { BAILE / FIESTA / MÚSICA: verbena, guateque, } \\
\text { tocadiscos, disco, discoteca, concierto } \\
\text { (DANCE / PARTY / MUSIC: open-air dance, bash, } \\
\text { record-player, record, disco, concert) }\end{array}$ & 52 & $\begin{array}{l}.096 \\
(0.269)\end{array}$ & $\begin{array}{l}.962 \\
(1.162)\end{array}$ & $\begin{array}{l}.462 \\
(1.549)\end{array}$ & .423 & 40 & $\begin{array}{l}.100 \\
(0.269)\end{array}$ & $\begin{array}{l}1.000 \\
(1.162)\end{array}$ & $\begin{array}{l}.750 \\
(1.549)\end{array}$ & .367 \\
\hline List 12 & $\begin{array}{l}\text { CALOR / FRÍO / INVIERNO: estufa, abrigo, } \\
\text { manta, bufanda, escalofrío, gorro } \\
\text { (HEAT / COLD / WINTER: stove, coat, blanket, } \\
\text { scarf, chill, bonnet) }\end{array}$ & 52 & $\begin{array}{l}.308 \\
(1.223)\end{array}$ & $\begin{array}{l}.712 \\
(1.534)\end{array}$ & $\begin{array}{l}.808 \\
(0.372)\end{array}$ & .269 & 40 & $\begin{array}{l}.225 \\
(1.223)\end{array}$ & $\begin{array}{l}.825 \\
(1.534)\end{array}$ & $\begin{array}{l}.825 \\
(0.372)\end{array}$ & .342 \\
\hline List 13 & $\begin{array}{l}\text { GAFAS / VER / VISTA: óptica, ojo, lentillas, } \\
\text { prismáticos, lupas, visión } \\
\text { (GLASSES / TO SEE / SIGHT: optics, eye, contact } \\
\text { lenses, binoculars, magnifiers, vision) }\end{array}$ & 52 & $\begin{array}{l}.058 \\
(1.098)\end{array}$ & $\begin{array}{l}.250 \\
(0.500)\end{array}$ & $\begin{array}{l}.500 \\
(0.302)\end{array}$ & .474 & 40 & $\begin{array}{l}.325 \\
(1.098)\end{array}$ & $\begin{array}{l}.400 \\
(0.500)\end{array}$ & $\begin{array}{l}.525 \\
(0.302)\end{array}$ & .533 \\
\hline List 14 & $\begin{array}{l}\text { DOLOR / HERIDA / SANGRE: daño, rasguño, } \\
\text { corte, pinchazo, ampolla, cicatriz } \\
\text { (PAIN / INJURY / BLOOD: damage, scratch, cut, } \\
\text { prick, blister, scar) }\end{array}$ & 52 & $\begin{array}{l}.673 \\
(1.135)\end{array}$ & $\begin{array}{l}.885 \\
(0.860)\end{array}$ & $\begin{array}{l}.115 \\
(0.330)\end{array}$ & .333 & 40 & $\begin{array}{l}.525 \\
(1.135)\end{array}$ & $\begin{array}{l}.725 \\
(0.860)\end{array}$ & $\begin{array}{l}.250 \\
(0.330)\end{array}$ & .492 \\
\hline List 15 & $\begin{array}{l}\text { FLOR / PLANTA / ÁRBOL: raíz, tallo, semilla, } \\
\text { laurel, brote, hojas }\end{array}$ & 52 & $\begin{array}{l}.231 \\
(0.714)\end{array}$ & $\begin{array}{l}.712 \\
(0.939)\end{array}$ & $\begin{array}{l}.154 \\
(0.813)\end{array}$ & .583 & 40 & $\begin{array}{l}.125 \\
(0.714)\end{array}$ & $\begin{array}{l}.825 \\
(0.939)\end{array}$ & $\begin{array}{l}.275 \\
(0.813)\end{array}$ & .575 \\
\hline
\end{tabular}


Table 2 (continued)

CRITICAL 1 / CRITICAL 2 / CRITICAL 3: Six Associated Words (approximated English translation)
Without-Explanation condition $n=153$

\begin{tabular}{llll}
\hline$n$ & ID (BAS) & & Intrusions \\
\cline { 2 - 3 } & Crit 1 & Crit 2 & Crit 3
\end{tabular}

With-Explanation condition $n=254$

\begin{tabular}{lllll}
\hline$n$ & ID (BAS) & & & Intrusions \\
\cline { 2 - 3 } & Crit 1 & Crit 2 & Crit 3 &
\end{tabular}

(FLOWER / PLANT / TREE: root, stem, seed, laurel, shoot, leaves)

List 16 AMOR / BODA / MATRIMONIO: nupcial, novios, enlace, compromiso, pareja, casar

(LOVE / WEDDING / MARRIAGE: bridal, newlyweds, bond, commitment, couple, to marry)

List 17 CIUDAD / LUGAR / PUEBLO: villa, municipio, localidad, comarca, localización, región (CITY / PLACE / VILLAGE: town, municipality, locality, district, location, region)

List 18 FÚTBOL / JUEGO / PELOTA: balón, deportes, béisbol, baloncesto, bola, tenis

(FOOTBALL / GAME / GOLF or TENNIS BALL: ball, sports, baseball, basketball, pellet, tennis)

List 19 DINERO / REY / RIQUEZA: poderoso, palacio, aristocracia, lujo, nobleza, poder

(MONEY / KING / WEALTH: powerful, palace, aristocracy, luxury, nobility, power)

List 20 DOLOR / ENFERMEDAD / GRIPE: contagio, anginas, constipado, vacuna, fiebre, resfriado

(PAIN / DISEASE / FLU: contagion, tonsillitis, to have a cold, vaccine, fever, cold)

List 21 DIVERSIÓN / FIESTA / MÚSICA: guateque, verbena, festival, baile, concierto, discoteca

(FUN / PARTY / MUSIC: bash, open-air dance, festival, dance, concert, disco)

List 22 FRÍO / HIELO / NIEVE: glaciar, Antártida, iceberg, pingüino, iglú, esquimal

(COLD / ICE / SNOW: glacier, Antarctica, iceberg, penguin, igloo, Eskimo)

List 23 BOMBA / FUEGO / GUERRA: explosión, cañón, misil, dinamita, destrucción, barricada

(BOMB / FIRE / WAR: explosion, cannon, missile, dynamite, destruction, barricade)

List 24 CIGARRO / HUMO / TABACO: cenicero, ceniza puro, fumar, pipa, mechero

(CIGARETTE / SMOKE / TOBACCO: ashtray, ash, cigar, to smoke, pipe, lighter)

List 25 IGLESIA / CURA / MONJE: clérigo, sotana, sacerdote, fraile, monasterio, monja

(CHURCH / CLERGYMAN / MONK: cleric, cassock, priest, friar, monastery, nun)

List 26 AGUA / MAR / RÍO: cauce, pez, orilla, lago, barca, bahía

(WATER / SEA / RIVER: riverbed, fish, shore, lake, boat, bay)

List 27 EJÉRCITO / MILITAR / SOLDADO: mili, coronel, cuartel, infantería, general, legión

(ARMY / MILITARY / SOLDIER: military service, colonel, barracks, infantry, general, legion)

List 28 DORMIR / NOCHE / SUEÑO: cama, pesadilla, camisón, descansar, soñar, cansancio

(TO SLEEP / NIGHT / DREAM: bed, nightmare, nightdress, to rest, to dream, tiredness)

List 29 ALEGRÍA / FELICIDAD / SONRISA: júbilo, risa, simpatía, optimismo, reír, carcajada

(JOY / HAPPINESS / SMILE: jubilation, laughter, sympathy, optimism, to laugh, laugh)

List 30 COMIDA / VERDE / VERDURA: alcachofa, coliflor, rábano, acelgas, pimiento, apio

(FOOD / GREEN / VEGETABLE: artichoke, cauliflower, radish, Swiss chard, pepper, celery)

$53 \quad .226$

$(0.449) \quad(0.507) \quad(0.962)$

667

$53 \quad .32$

$(1.020)-(0.200)-(0.620)$

$0.200)$

$(0.620)$

53.283

$(0.554) \quad(0.538) \quad(0.253)$

.623

2057

$\begin{array}{llll}53 & .057 \quad .755 & .094\end{array}$

$\begin{array}{lll}(0.369) \quad(0.794) \quad(0.919) & 094\end{array}$

.679

$53-340$

$\begin{array}{llll}53 & .340 & .830 & .566 \\ & (0.285) & (1.445) & (0.860)\end{array}$

.396

53

3.830

(1.446) (1.582) (0.206)

.365

(1)

$\begin{array}{llll}53 & .245 & .057 & .698\end{array}$

$\begin{array}{lll}(0.760) \quad(0.285) \quad(1.045) & 0\end{array}$

660

3302

$\begin{array}{lll}(1.144) & (0.553) & (0.443)\end{array}$

.528

$53 \quad .623 \quad .340$

(0.702) (1.652)

.075

(0.612)

.635

53.491

$\begin{array}{lll}(0.922) & (1.038) & (1.198)\end{array}$

$53 \quad .660$

$\begin{array}{ll}.283 & .170\end{array}$

$\begin{array}{llll}53 & .698 & .321 & .415\end{array}$

$(1.410) \quad(0.265) \quad(0.611)$

.459

$372 \quad 415 \quad 113$

$\begin{array}{llll}(1.137) & (0.394) & (0.384)\end{array}$

.616

$53 \quad .264$

(0.547)

.057

(0.521)

.698

$(0.850)$ $\begin{array}{lllll}35 & .486 & .771 & .514 & .371 \\ & (0.665) & (1.310) & (0.605) & \end{array}$

$\begin{array}{llll}35 & .200 & .343 & .257\end{array}$

$\begin{array}{lll}(0.449) \quad(0.507) & (0.962)\end{array}$

$\begin{array}{llll}35 & .171 & .171 & .229\end{array}$

$\begin{array}{lll}(1.020) \quad(0.200) \quad(0.620) & 0\end{array}$

$\begin{array}{llll}35 & .657 & .629 & .257\end{array}$

$(0.554) \quad(0.538) \quad(0.253)$

$\begin{array}{llll}35 & .286 & .886 & .171 \\ & (0.369) & (0.794) & (0.919)\end{array}$

.543

$\begin{array}{llll}35 & .314 & .971 & .400 \\ & (0.285) & (1.445) & (0.860)\end{array}$

.429

$35 \quad .971$

$\begin{array}{lll}.971 & .800 & .200 \\ (1.446) & (1.582) & (0.206)\end{array}$

.333

(1)

$\begin{array}{lll}(0.760) & (0.285) & (1.045)\end{array}$

$\begin{array}{lllll}35 & .257 & .371 & .657 & .552\end{array}$

$(1.144) \quad(0.553) \quad(0.443)$

$\begin{array}{lllll}35 & .600 & .057 & .000 & .771\end{array}$

$(0.702) \quad(1.652) \quad(0.612)$

$\begin{array}{lllll}35 & .886 & .057 & .600 & .381\end{array}$

$\begin{array}{lll}(0.922) \quad(1.038) \quad(1.198) & \end{array}$

$\begin{array}{llll}35 & .857 & .400 \quad .257\end{array}$

$\begin{array}{lll}(0.884) & (0.514) \quad(0.454)\end{array}$

.457

$\begin{array}{llll}35 & .771 & .371 & .457\end{array}$

$(1.410) \quad(0.265) \quad(0.611)$

.419

571

$\begin{array}{lll}(1.137) & (0.394) & (0.384)\end{array}$

$\begin{array}{llll}35 & .343 & .171 & .857\end{array}$

$\begin{array}{lll}(0.547) & (0.521) \quad(0.850)\end{array}$ 
Table 2 (continued)

CRITICAL 1 / CRITICAL 2 / CRITICAL 3: Six Associated Words (approximated English translation)
Without-Explanation condition $n=153$

$n \quad$ ID

\begin{tabular}{c}
\hline List 31 CINE / PELÍCULA / TEATRO: escena, estreno, \\
escenario, trama, actor, ficción \\
(CINEMA / FILM / THEATRE: scene, premiere, \\
stage, plot, actor, fiction)
\end{tabular}

List 32 ANIMAL / GATO / LEÓN: felino, fiereza, zarpa, veterinaria, garra, hiena

(ANIMAL / CAT / LION: feline, ferocity, paw, veterinary, claw, hyena)

List 33 ARMA / DISPARO / PISTOLA: revólver, bala, rifle, fusil, metralleta, escopeta

(WEAPON / SHOT / PISTOL: revolver, bullet, rifle, handgun, machine gun, shotgun)

List 34 CAMA / DESCANSO / DORMIR: almohada, lecho, sueño, sábana, sofá, cansancio (BED / REST / TO SLEEP: pillow, resting place, dream, sheet, sofa, tiredness)

List 35 CÁRCEL / PRESO / PRISIÓN: rejas, prisionero, celda, reo, presidio, reclusión

(JAIL / INMATE / PRISON: bars, prisoner, cell, offender, penitentiary, imprisonment)

List 36 ALCOHOL / BEBIDA / FIESTA: vodka, juerga, ron, licor, borracho, borrachera

(ALCOHOL / DRINK / PARTY: vodka, spree, rum, liqueur, drunk, drunkenness)

List 37 FLOR / OLOR / ROSA: jazmín, clavel, amapola, tulipán, aroma, rosal

(FLOWER / SMELL / ROSE: jasmine, carnation, poppy, tulip, aroma, rosebush)

List 38 CIGARRO / FUMAR / TABACO: cenicero, pipa, humo, mechero, puro, pulmones

(CIGARETTE / TO SMOKE / TOBACCO: ashtray, pipe, smoke, lighter, cigar, lungs)

List 39 IGLESIA / CURA / MONJA: sotana, convento, sacerdote, religiosa, católica, fraile

(CHURCH / CLERGYMAN / NUN: cassock, convent, priest, religious woman, Catholic, friar)

List 40 AGUA / MAR / PLAYA: olas, orilla, bahía, costa, nadar, puerto

(WATER / SEA / BEACH: waves, shore, bay, coast, to swim, port)

List 41 MIEDO / PÁNICO / TEMOR: terror, pavor, horror, aterrorizado, susto, temeroso

(FEAR / PANIC / AWE: terror, dread, horror, terrified, scare, fearful)

List 42 EJÉRCITO / GUERRA / MILITAR: batallón, soldado, infantería, milicia, coronel, regimiento

(ARMY / WAR / MILITARY: battalion, soldier, infantry, militia, colonel, regiment)

List 43 ABRIGO / CALOR / FRÍO: bufanda, manta, invierno, jersey, escalofrío, gabardina

(COAT / HEAT / COLD: scarf, blanket, winter, jersey, chill, raincoat)

List 44 DOLOR / MUERTE / TRISTEZA: fallecimiento, pésame, entierro, pena, agonía, funeral

(PAIN / DEATH / SADNESS: demise, condolence, burial, sorrow, agony, funeral)

List 45 BOSQUE / VERDE / ÁRBOL: pino, prado, frondoso, nogal, vegetación, abeto

(FOREST / GREEN / TREE: pine, meadow, leafy, walnut, vegetation, fir)

List 46 AGUA / BARCO / MAR: navegación, puerto, navío, marinero, flota, océano

(WATER / BOAT / SEA: navigation, port, ship, sailor, fleet, ocean)

\begin{tabular}{|c|c|c|c|c|c|c|c|c|c|}
\hline 75 & $\begin{array}{l}.493 \\
(0.545)\end{array}$ & $\begin{array}{l}.400 \\
(1.475)\end{array}$ & $\begin{array}{l}.867 \\
(1.065)\end{array}$ & .396 & 32 & $\begin{array}{l}.438 \\
(0.545)\end{array}$ & $\begin{array}{l}.406 \\
(1.475)\end{array}$ & $\begin{array}{l}.875 \\
(1.065)\end{array}$ & .427 \\
\hline 75 & $\begin{array}{l}.933 \\
(0.630)\end{array}$ & $\begin{array}{l}.200 \\
(0.785)\end{array}$ & $\begin{array}{l}.013 \\
(0.705)\end{array}$ & .467 & 32 & $\begin{array}{l}.813 \\
(0.630)\end{array}$ & $\begin{array}{l}.406 \\
(0.785)\end{array}$ & $\begin{array}{l}.188 \\
(0.705)\end{array}$ & .458 \\
\hline 75 & $\begin{array}{l}.840 \\
(0.865)\end{array}$ & $\begin{array}{l}.053 \\
(0.390)\end{array}$ & $\begin{array}{l}.040 \\
(0.845)\end{array}$ & .622 & 32 & $\begin{array}{l}.875 \\
(0.865)\end{array}$ & $\begin{array}{l}.125 \\
(0.390)\end{array}$ & $\begin{array}{l}.156 \\
(0.845)\end{array}$ & .604 \\
\hline 75 & $\begin{array}{l}.360 \\
(1.332)\end{array}$ & $\begin{array}{l}.373 \\
(0.254)\end{array}$ & $\begin{array}{l}.813 \\
(0.855)\end{array}$ & .440 & 32 & $\begin{array}{l}.531 \\
(1.332)\end{array}$ & $\begin{array}{l}.375 \\
(0.254)\end{array}$ & $\begin{array}{l}.906 \\
(0.855)\end{array}$ & .396 \\
\hline 75 & $\begin{array}{l}.893 \\
(2.190)\end{array}$ & $\begin{array}{l}.080 \\
(0.550)\end{array}$ & $\begin{array}{l}.187 \\
(0.350)\end{array}$ & .524 & 32 & $\begin{array}{l}.938 \\
(2.190)\end{array}$ & $\begin{array}{l}.063 \\
(0.550)\end{array}$ & $\begin{array}{l}.281 \\
(0.350)\end{array}$ & .542 \\
\hline 75 & $\begin{array}{l}.720 \\
(1.055)\end{array}$ & $\begin{array}{l}.227 \\
(0.680)\end{array}$ & $\begin{array}{l}.707 \\
(0.560)\end{array}$ & .409 & 32 & $\begin{array}{l}.813 \\
(1.055)\end{array}$ & $\begin{array}{l}.094 \\
(0.680)\end{array}$ & $\begin{array}{l}.813 \\
(0.560)\end{array}$ & .427 \\
\hline 75 & $\begin{array}{l}.920 \\
(1.983)\end{array}$ & $\begin{array}{l}.360 \\
(0.645)\end{array}$ & $\begin{array}{l}.000 \\
(0.394)\end{array}$ & .542 & 32 & $\begin{array}{l}.969 \\
(1.983)\end{array}$ & $\begin{array}{l}.250 \\
(0.645)\end{array}$ & $\begin{array}{l}.000 \\
(0.394)\end{array}$ & .583 \\
\hline 75 & $\begin{array}{l}.133 \\
(0.794)\end{array}$ & $\begin{array}{l}.640 \\
(0.597)\end{array}$ & $\begin{array}{l}.560 \\
(0.593)\end{array}$ & .471 & 32 & $\begin{array}{l}.250 \\
(0.794)\end{array}$ & $\begin{array}{l}.750 \\
(0.597)\end{array}$ & $\begin{array}{l}.625 \\
(0.593)\end{array}$ & .458 \\
\hline 75 & $\begin{array}{l}.573 \\
(0.765)\end{array}$ & $\begin{array}{l}.147 \\
(1.205)\end{array}$ & $\begin{array}{l}.093 \\
(1.010)\end{array}$ & .711 & 32 & $\begin{array}{l}.750 \\
(0.765)\end{array}$ & $\begin{array}{l}.313 \\
(1.205)\end{array}$ & $\begin{array}{l}.125 \\
(1.010)\end{array}$ & .594 \\
\hline 75 & $\begin{array}{l}.307 \\
(0.490)\end{array}$ & $\begin{array}{l}.493 \\
(1.915)\end{array}$ & $\begin{array}{l}.600 \\
(0.820)\end{array}$ & .453 & 32 & $\begin{array}{l}.250 \\
(0.490)\end{array}$ & $\begin{array}{l}.688 \\
(1.915)\end{array}$ & $\begin{array}{l}.656 \\
(0.820)\end{array}$ & .438 \\
\hline 75 & $\begin{array}{l}.920 \\
(2.340)\end{array}$ & $\begin{array}{l}.120 \\
(0.255)\end{array}$ & $\begin{array}{l}.027 \\
(0.230)\end{array}$ & .524 & 32 & $\begin{array}{l}.969 \\
(2.340)\end{array}$ & $\begin{array}{l}.031 \\
(0.255)\end{array}$ & $\begin{array}{l}.000 \\
(0.230)\end{array}$ & .615 \\
\hline 75 & $\begin{array}{l}.640 \\
(1.104)\end{array}$ & $\begin{array}{l}.720 \\
(0.769)\end{array}$ & $\begin{array}{l}.227 \\
(0.404)\end{array}$ & .427 & 32 & $\begin{array}{l}.625 \\
(1.104)\end{array}$ & $\begin{array}{l}.813 \\
(0.769)\end{array}$ & $\begin{array}{l}.219 \\
(0.404)\end{array}$ & .417 \\
\hline 75 & $\begin{array}{l}.200 \\
(0.489)\end{array}$ & $\begin{array}{l}.040 \\
(0.514)\end{array}$ & $\begin{array}{l}.893 \\
(1.503)\end{array}$ & .507 & 32 & $\begin{array}{l}.469 \\
(0.489)\end{array}$ & $\begin{array}{l}.063 \\
(0.514)\end{array}$ & $\begin{array}{l}.969 \\
(1.503)\end{array}$ & .385 \\
\hline 75 & $\begin{array}{l}.253 \\
(0.590)\end{array}$ & $\begin{array}{l}.867 \\
(2.009)\end{array}$ & $\begin{array}{l}.453 \\
(0.430)\end{array}$ & .458 & 32 & $\begin{array}{l}.531 \\
(0.590)\end{array}$ & $\begin{array}{l}.813 \\
(2.009)\end{array}$ & $\begin{array}{l}.531 \\
(0.430)\end{array}$ & .375 \\
\hline 75 & $\begin{array}{l}.467 \\
(0.546)\end{array}$ & $\begin{array}{l}.253 \\
(0.928)\end{array}$ & $\begin{array}{l}.480 \\
(1.424)\end{array}$ & .560 & 32 & $\begin{array}{l}.656 \\
(0.546)\end{array}$ & $\begin{array}{l}.313 \\
(0.928)\end{array}$ & $\begin{array}{l}.625 \\
(1.424)\end{array}$ & .469 \\
\hline 74 & $\begin{array}{l}.041 \\
(0.229)\end{array}$ & $\begin{array}{l}.622 \\
(2.170)\end{array}$ & $\begin{array}{l}.608 \\
(1.308)\end{array}$ & .541 & 46 & $\begin{array}{l}.152 \\
(0.229)\end{array}$ & $\begin{array}{l}.783 \\
(2.170)\end{array}$ & $\begin{array}{l}.761 \\
(1.308)\end{array}$ & .420 \\
\hline
\end{tabular}

With-Explanation condition $n=254$

$n \quad \mathrm{ID}(\mathrm{BAS})$

\begin{tabular}{|c|c|c|c|c|c|c|c|c|}
\hline \multicolumn{3}{|c|}{ ID (BAS) } & \multirow[t]{2}{*}{ Intrusions } & \multirow[t]{2}{*}{$n$} & \multicolumn{3}{|c|}{ ID (BAS) } & \multirow[t]{2}{*}{ Intrusions } \\
\hline Crit 1 & Crit 2 & Crit 3 & & & Crit 1 & Crit 2 & Crit 3 & \\
\hline $\begin{array}{l}.493 \\
(0.545)\end{array}$ & $\begin{array}{l}.400 \\
(1.475)\end{array}$ & $\begin{array}{l}.867 \\
(1.065)\end{array}$ & .396 & 32 & $\begin{array}{l}.438 \\
(0.545)\end{array}$ & $\begin{array}{l}.406 \\
(1.475)\end{array}$ & $\begin{array}{l}.875 \\
(1.065)\end{array}$ & .427 \\
\hline
\end{tabular}


Table 2 (continued)

CRITICAL 1 / CRITICAL 2 / CRITICAL 3: Six Associated Words (approximated English translation)
Without-Explanation condition $n=153$

\begin{tabular}{|c|c|c|c|c|c|c|c|c|c|c|c|}
\hline & \multirow{3}{*}{ tion) } & \multirow{3}{*}{$n$} & \multirow{2}{*}{\multicolumn{3}{|c|}{ ID (BAS) }} & \multirow{3}{*}{ Intrusions } & \multirow{3}{*}{$n$} & \multirow{2}{*}{\multicolumn{3}{|c|}{ ID (BAS) }} & \\
\hline & & & & & & & & & & & \multirow[t]{2}{*}{ Intrusions } \\
\hline & & & Crit 1 & Crit 2 & Crit 3 & & & Crit 1 & Crit 2 & Crit 3 & \\
\hline List 47 & $\begin{array}{l}\text { HORROR / MIEDO / TERROR: pavor, temor, } \\
\text { pánico, espanto, susto, pesadilla } \\
\text { (HORROR / FEAR / TERROR: dread, awe, panic, } \\
\text { fright, scare, nightmare) }\end{array}$ & 74 & $\begin{array}{l}.176 \\
(0.420)\end{array}$ & $\begin{array}{l}.919 \\
(2.070)\end{array}$ & $\begin{array}{l}.203 \\
(0.285)\end{array}$ & .500 & 46 & $\begin{array}{l}.152 \\
(0.420)\end{array}$ & $\begin{array}{l}.913 \\
(2.070)\end{array}$ & $\begin{array}{l}.196 \\
(0.285)\end{array}$ & .536 \\
\hline List 48 & $\begin{array}{l}\text { BAÑO / DUCHA / LIMPIEZA: gel, toalla, bañera, } \\
\text { servicio, lavabo, jabón } \\
\text { (BATHROOM / SHOWER / CLEANING: gel, } \\
\text { towel, bath, toilet, sink, soap) }\end{array}$ & 74 & $\begin{array}{l}.486 \\
(0.905)\end{array}$ & $\begin{array}{l}.419 \\
(0.834)\end{array}$ & $\begin{array}{l}.257 \\
(0.249)\end{array}$ & .590 & 46 & $\begin{array}{l}.522 \\
(0.905)\end{array}$ & $\begin{array}{l}.457 \\
(0.834)\end{array}$ & $\begin{array}{l}.261 \\
(0.249)\end{array}$ & .580 \\
\hline List 49 & $\begin{array}{l}\text { ROPA / TRAJE / VESTIDO: modista, percha, } \\
\text { vestir, tela, elegante, tejido } \\
\text { (CLOTHING / COSTUME / DRESS: dressmaker, } \\
\text { hanger, to dress, cloth, elegant, fabric) }\end{array}$ & 74 & $\begin{array}{l}.554 \\
(1.502)\end{array}$ & $\begin{array}{l}.108 \\
(0.461)\end{array}$ & $\begin{array}{l}.162 \\
(0.281)\end{array}$ & .703 & 46 & $\begin{array}{l}.630 \\
(1.502)\end{array}$ & $\begin{array}{l}.152 \\
(0.461)\end{array}$ & $\begin{array}{l}.217 \\
(0.281)\end{array}$ & .652 \\
\hline List 50 & $\begin{array}{l}\text { ENSALADA / VERDE / VERDURA: lechuga, } \\
\text { alcachofa, pimiento, tomate, coliflor, rábano } \\
\text { (SALAD / GREEN / VEGETABLE: lettuce, } \\
\text { artichoke, pepper, tomato, cauliflower, radish) }\end{array}$ & 74 & $\begin{array}{l}.230 \\
(0.689)\end{array}$ & $\begin{array}{l}.041 \\
(0.591)\end{array}$ & $\begin{array}{l}.541 \\
(0.726)\end{array}$ & .712 & 46 & $\begin{array}{l}.174 \\
(0.689)\end{array}$ & $\begin{array}{l}.109 \\
(0.591)\end{array}$ & $\begin{array}{l}.761 \\
(0.726)\end{array}$ & .638 \\
\hline List 51 & $\begin{array}{l}\text { ACTOR / PELÍCULA / TEATRO: escena, } \\
\text { interpretación, escenario, actriz, intérprete, actuar } \\
\text { (ACTOR / FILM / THEATRE: scene, interpretation, } \\
\text { stage, actress, interpreter, to act) }\end{array}$ & 74 & $\begin{array}{l}.257 \\
(0.740)\end{array}$ & $\begin{array}{l}.189 \\
(0.410)\end{array}$ & $\begin{array}{l}.770 \\
(1.560)\end{array}$ & .568 & 46 & $\begin{array}{l}.239 \\
(0.740)\end{array}$ & $\begin{array}{l}.283 \\
(0.410)\end{array}$ & $\begin{array}{l}.804 \\
(1.560)\end{array}$ & .551 \\
\hline List 52 & $\begin{array}{l}\text { ANIMAL / GATO / PERRO: maullido, mascota, } \\
\text { maullar, pulgas, rabo, veterinaria } \\
\text { (ANIMAL / CAT / DOG: miaow, pet, to meow, } \\
\text { fleas, tail, veterinary) }\end{array}$ & 74 & $\begin{array}{l}.500 \\
(0.405)\end{array}$ & $\begin{array}{l}.757 \\
(1.855)\end{array}$ & $\begin{array}{l}.230 \\
(1.735)\end{array}$ & .428 & 46 & $\begin{array}{l}.696 \\
(0.405)\end{array}$ & $\begin{array}{l}.739 \\
(1.855)\end{array}$ & $\begin{array}{l}.217 \\
(1.735)\end{array}$ & .384 \\
\hline List 53 & $\begin{array}{l}\text { ARMA / MUERTE / PISTOLA: balas, disparo, } \\
\text { revólver, rifle, fusil, metralleta } \\
\text { (WEAPON / DEATH / PISTOL: bullets, shot, } \\
\text { revolver, rifle, handgun, machine gun) }\end{array}$ & 74 & $\begin{array}{l}.581 \\
(0.755)\end{array}$ & $\begin{array}{l}.122 \\
(0.390)\end{array}$ & $\begin{array}{l}.230 \\
(1.195)\end{array}$ & .671 & 46 & $\begin{array}{l}.543 \\
(0.755)\end{array}$ & $\begin{array}{l}.457 \\
(0.390)\end{array}$ & $\begin{array}{l}.152 \\
(1.195)\end{array}$ & .601 \\
\hline List 54 & $\begin{array}{l}\text { COLONIA / FLOR / OLOR: jazmín, perfume, } \\
\text { aroma, fragancia, esencia, violeta } \\
\text { (COLOGNE / FLOWER / SMELL: jasmine, } \\
\text { perfume, aroma, fragrance, essence, violet) }\end{array}$ & 74 & $\begin{array}{l}.527 \\
(0.335)\end{array}$ & $\begin{array}{l}.459 \\
(0.760)\end{array}$ & $\begin{array}{l}.784 \\
(1.405)\end{array}$ & .360 & 46 & $\begin{array}{l}.413 \\
(0.335)\end{array}$ & $\begin{array}{l}.587 \\
(0.760)\end{array}$ & $\begin{array}{l}.870 \\
(1.405)\end{array}$ & .319 \\
\hline List 55 & $\begin{array}{l}\text { ALCOHOL / BEBIDA / VINO: copa, licor, } \\
\text { borracho, botella, sobriedad, litro } \\
\text { (ALCOHOL / DRINK / WINE: glass, liqueur, } \\
\text { drunk, bottle, soberness, liter) }\end{array}$ & 74 & $\begin{array}{l}.568 \\
(0.846)\end{array}$ & $\begin{array}{l}.135 \\
(0.392)\end{array}$ & $\begin{array}{l}.027 \\
(0.671)\end{array}$ & .716 & 46 & $\begin{array}{l}.804 \\
(0.846)\end{array}$ & $\begin{array}{l}.196 \\
(0.392)\end{array}$ & $\begin{array}{l}.065 \\
(0.671)\end{array}$ & .609 \\
\hline List 56 & $\begin{array}{l}\text { AMIGO / AMOR / CARIÑO: afecto, abrazo, } \\
\text { aprecio, novio, amistad, fiel } \\
\text { (FRIEND / LOVE / FONDNESS: affection, hug, } \\
\text { esteem, boyfriend, friendship, faithful) }\end{array}$ & 74 & $\begin{array}{l}.068 \\
(0.380)\end{array}$ & $\begin{array}{l}.676 \\
(0.665)\end{array}$ & $\begin{array}{l}.419 \\
(1.200)\end{array}$ & .595 & 46 & $\begin{array}{l}.087 \\
(0.380)\end{array}$ & $\begin{array}{l}.783 \\
(0.665)\end{array}$ & $\begin{array}{l}.609 \\
(1.200)\end{array}$ & .493 \\
\hline List 57 & $\begin{array}{l}\text { GAFAS / OJO / VISTA: ocular, óptica, miopía, } \\
\text { oculista, lentillas, visión } \\
\text { (GLASSES / EYE / SIGHT: ocular, optics, myopia, } \\
\text { oculist, contact lenses, vision) }\end{array}$ & 74 & $\begin{array}{l}.473 \\
(1.590)\end{array}$ & $\begin{array}{l}.784 \\
(1.190)\end{array}$ & $\begin{array}{l}.189 \\
(0.395)\end{array}$ & .419 & 46 & $\begin{array}{l}.674 \\
(1.590)\end{array}$ & $\begin{array}{l}.783 \\
(1.190)\end{array}$ & $\begin{array}{l}.261 \\
(0.395)\end{array}$ & .370 \\
\hline List 58 & $\begin{array}{l}\text { LUZ / NOCHE / SOL: día, luna, amanecer, sombra, } \\
\text { estrella, atardecer } \\
\text { (LIGHT / NIGHT / SUN: day, moon, dawn, } \\
\text { shadow, star, dusk) }\end{array}$ & 74 & $\begin{array}{l}.162 \\
(0.317)\end{array}$ & $\begin{array}{l}.243 \\
(1.021)\end{array}$ & $\begin{array}{l}.419 \\
(0.991)\end{array}$ & .635 & 46 & $\begin{array}{l}.174 \\
(0.317)\end{array}$ & $\begin{array}{l}.348 \\
(1.021)\end{array}$ & $\begin{array}{l}.457 \\
(0.991)\end{array}$ & .601 \\
\hline List 59 & $\begin{array}{l}\text { ALEGRÍA / FELICIDAD / RISA: carcajada, } \\
\text { humor, sonrisa, gracia, diversión, simpatía } \\
\text { (JOY / HAPPINESS / LAUGHTER: laugh, humor, } \\
\text { smile, jocularity, fun, sympathy) }\end{array}$ & 74 & $\begin{array}{l}.378 \\
(0.618)\end{array}$ & $\begin{array}{l}.351 \\
(0.270)\end{array}$ & $\begin{array}{l}.270 \\
(1.185)\end{array}$ & .649 & 46 & $\begin{array}{l}.565 \\
(0.618)\end{array}$ & $\begin{array}{l}.522 \\
(0.270)\end{array}$ & $\begin{array}{l}.261 \\
(1.185)\end{array}$ & .522 \\
\hline List 60 & $\begin{array}{l}\text { CASA / EDIFICIO / PISO: vivienda, portal, } \\
\text { fachada, arquitecto, ático, viga } \\
\text { (HOME / BUILDING / FLOOR: dwelling, } \\
\text { doorway, facade, architect, attic, beam) }\end{array}$ & 74 & $\begin{array}{l}.568 \\
(1.565)\end{array}$ & $\begin{array}{l}.419 \\
(0.435)\end{array}$ & $\begin{array}{l}.203 \\
(0.298)\end{array}$ & .586 & 46 & $\begin{array}{l}.609 \\
(1.565)\end{array}$ & $\begin{array}{l}.413 \\
(0.435)\end{array}$ & $\begin{array}{l}.087 \\
(0.298)\end{array}$ & .601 \\
\hline
\end{tabular}

With-Explanation condition $n=254$

Theme identifiability (ID) proportions and backward associative strength (BAS) values are specified for each critical word per list (Crit 1, Crit 2, Crit 3) in the without- and with-explanation conditions. Intrusion rate and number of participants $(n)$ are specified per list 


\section{References}

Alonso, M. A., Fernandez, A., \& Díez, E. (2015). Subjective age-ofacquisition norms for 7,039 Spanish words. Behavior Research Methods, 47, 268-274. doi:10.3758/s13428-014-0454-2

Arndt, J., \& Gould, C. (2006). An examination of two process theories of false recognition. Memory, 14, 814-833. doi:10.1080/ 09658210600680749

Beato, M. S., \& Arndt, J. (2014). False recognition production indexes in forward associative strength (FAS) lists with three critical words. Psicothema, 26, 457-463. doi:10.7334/psicothema2014.79

Beato, M. S., Boldini, A., \& Cadavid, S. (2012). False memory and level of processing effect: An event-related potential study. NeuroReport, 23, 804-808. doi:10.1097/WNR.0b013e32835734de

Beato, M. S., Cadavid, S., Pulido, R. F., \& Pinho, M. S. (2013). No effect of stress on false recognition. Psicothema, 25, 25-30. doi:10.7334/ psicothema2012.158

Beato, M. S., \& Díez, E. (2011). False recognition production indexes in Spanish for 60 DRM lists with three critical words. Behavior Research Methods, 43, 499-507. doi:10.3758/s13428-010-0045-9

Boldini, A., Beato, M. S., \& Cadavid, S. (2013). Modality-match effect in false recognition: An event-related potential study. NeuroReport, 24, 108-113. doi:10.1097/WNR.0b013e32835c93e3

Brainerd, C. J., \& Reyna, V. F. (1990). Gist is the grist: Fuzzy-trace theory and the new intuitionism. Developmental Review, 10, 3-47. doi:10. 1016/0273-2297(90)90003-M

Brainerd, C. J., Reyna, V. F., \& Ceci, S. J. (2008). Developmental reversals in false memory: A review of data and theory. Psychological Bulletin, 134, 343-382. doi:10.1037/0033-2909.134.3.343

Cadavid, S., Beato, M. S., \& Fernandez, A. (2012). Falso reconocimiento en listas DRM con tres palabras críticas: Asociación directa vs. inversa [False recognition in DRM lists with three critical words: Forward versus backward association]. Psicológica, 33, 39-58.

Carneiro, P., \& Fernandez, A. (2013). Retrieval dynamics in false recall: Revelations from identifiability manipulations. Psychonomic Bulletin \& Review, 20, 488-495. doi:10.3758/s13423-012-0361-4

Carneiro, P., Fernandez, A., \& Dias, A. R. (2009). The influence of theme identifiability on false memories: Evidence for age-dependent opposite effects. Memory \& Cognition, 37, 115-129. doi:10.3758/MC. 37.2.115

Carneiro, P., Fernandez, A., Diez, E., Garcia-Marques, L., Ramos, T., \& Ferreira, M. B. (2012). "Identify-to-reject": A specific strategy to avoid false memories in the DRM paradigm. Memory \& Cognition, 40, 252-265. doi:10.3758/s13421-011-0152-6

Carneiro, P., Ramos, T., Costa, R. C., Garcia-Marques, L., \& Albuquerque, P. (2011). Identificabilidade dos temas de listas associativas backward: Contributos para o estudo das memórias falsas [Theme identifiability of backward associative lists: Contribution to false memory research]. Laboratório de Psicologia, 9, 23-34. doi:10.14417/lp.634

Curran, T., Schacter, D. L., Johnson, M. K., \& Spinks, R. (2001). Brain potentials reflect behavioral differences in true and false recognition. Journal of Cognitive Neuroscience, 13, 201-216. doi:10.1162/ 089892901564261

Deese, J. (1959). On the prediction of occurrence of particular verbal intrusions in immediate recall. Journal of Experimental Psychology, 58, 17-22. doi:10.1037/h0046671

Del Prete, F., Mirandola, C., Konishi, M., Cornoldi, C., \& Ghetti, S. (2014). Paradoxical effects of warning in the production of children's false memories. Journal of Cognition and Development, 15, 94-109. doi:10.1080/15248372.2012.721036

Fernandez, A., Díez, E., \& Alonso, M. A. (2009). Normas de asociación libre en castellano [Online database]. Retrieved July 15, 2015, from www.usal.es/gimc
Flegal, K. E., \& Reuter-Lorenz, P. A. (2014). Get the gist? The effects of processing depth on false recognition in short-term and long-term memory. Memory \& Cognition, 42, 701-711. doi:10.3758/s13421013-0391-9

Gallo, D. A. (2004). Using recall to reduce false recognition: Diagnostic and disqualifying monitoring. Journal of Experimental Psychology: Learning, Memory, and Cognition, 30, 120-128. doi:10.1037/02787393.30.1.120

Gallo, D. A. (2006). Associative illusions of memory: False memory research in DRM and related tasks. New York: Psychology Press.

Gallo, D. A. (2010). False memories and fantastic beliefs: 15 years of the DRM illusion. Memory \& Cognition, 38, 833-848. doi:10.3758/ MC.38.7.833

Gallo, D. A., Roberts, M. J., \& Seamon, J. G. (1997). Remembering words not presented in lists: Can we avoid creating false memories? Psychonomic Bulletin \& Review, 4, 271-276. doi:10.3758/ BF03209405

Gallo, D. A., \& Roediger, H. L., III. (2002). Variability among word lists in eliciting memory illusions: Evidence for associative activation and monitoring. Journal of Memory and Language, 47, 469-497. doi:10.1016/S0749-596X(02)00013-X

Gallo, D. A., Roediger, H. L., III, \& McDermott, K. B. (2001). Associative false recognition occurs without strategic criterion shifts. Psychonomic Bulletin \& Review, 8, 579-586. doi:10.3758/ BF03196194

Graham, L. M. (2007). Need for cognition and false memory in the Deese-Roediger-McDermott paradigm. Personality and Individual Differences, 42, 409-418. doi:10.1016/j.paid.2006.07. 012

Howe, M. L., Wimmer, M. C., \& Blease, K. (2009). The role of associative strength in children's false memory illusions. Memory, 17, 8-16. doi: $10.1080 / 09658210802438474$

Knott, L. M., Dewhurst, S. A., \& Howe, M. L. (2012). What factors underlie associative and categorical memory illusions? The roles of backward associative strength and interitem connectivity. Journal of Experimental Psychology: Learning, Memory, and Cognition, 38, 229-239. doi:10.1037/a0025201

Luck, S. J. (2005). An introduction to the event-related potential technique. Cambridge: MIT Press.

McCabe, D. P., \& Smith, A. D. (2002). The effect of warnings on false memories in young and older adults. Memory \& Cognition, 30, 1065-1077. doi:10.3758/BF03194324

McDermott, K. B., \& Roediger, H. L., III. (1998). Attempting to avoid illusory memories: Robust false recognition of associates persists under conditions of explicit warnings and immediate testing. Journal of Memory and Language, 39, 508-520. doi:10.1006/ jmla.1998.2582

McEvoy, C. L., Nelson, D. L., \& Komatsu, T. (1999). What is the connection between true and false memories? The differential roles of interitem associations in recall and recognition. Journal of Experimental Psychology: Learning, Memory, and Cognition, 25, 1177-1194. doi:10.1037/0278-7393.25.5.1177

Multhaup, K. S., \& Conner, C. A. (2002). The effects of considering nonlist sources on the Deese-Roediger-McDermott memory illusion. Journal of Memory and Language, 47, 214-228. doi:10. 1016/S0749-596X(02) 00007-4

Neuschatz, J. S., Benoit, G. E., \& Payne, D. G. (2003). Effective warnings in the Deese-Roediger-McDermott false-memory paradigm: The role of identifiability. Journal of Experimental Psychology: Learning, Memory, and Cognition, 29, 35-41. doi:10.1037/02787393.29.1.35

Peters, M. J. V., Jelicic, M., Gorski, B., Sijstermans, K., Giesbrecht, T., \& Merckelbach, H. (2008). The corrective effects of warning on false memories in the DRM paradigm are limited to full attention conditions. Acta Psychologica, 129, 308-314. doi:10.1016/j.actpsy.2008. 08.007 
Pimentel, E., \& Albuquerque, P. B. (2013). Effect of divided attention on the production of false memories in the DRM paradigm: A study of dichotic listening and shadowing. Psicológica, 34, 285-298.

Reyna, V. F., \& Brainerd, C. J. (1995). Fuzzy-trace theory: An interim synthesis. Learning and Individual Differences, 7, 1-75. doi:10. 1016/1041-6080(95)90031-4

Robinson, K. J., \& Roediger, H. L., III. (1997). Associative processes in false recall and false recognition. Psychological Science, 8, 231237. doi:10.1111/j.1467-9280.1997.tb00417.x

Roediger, H. L., III, Balota, D. A., \& Watson, J. M. (2001a). Spreading activation and arousal of false memories. In H. L. Roediger III, J. S. Nairne, I. Neath, \& A. M. Surprenant (Eds.), The nature of remembering: Essays in honor of Robert G. Crowder (pp. 95-115). Washington DC: American Psychological Association.

Roediger, H. L., III, \& McDermott, K. B. (1995). Creating false memories: Remembering words not presented in lists. Journal of Experimental Psychology: Learning, Memory, and Cognition, 21, 803-814. doi:10.1037/0278-7393.21.4.803

Roediger, H. L., III, Watson, J. M., McDermott, K. B., \& Gallo, D. A. (2001b). Factors that determine false recall: A multiple regression analysis. Psychonomic Bulletin \& Review, 8, 385-407. doi:10.3758/ BF03196177

Stadler, M. A., Roediger, H. L., III, \& McDermott, K. B. (1999). Norms for word lists that create false memories. Memory \& Cognition, 27, 494-500. doi:10.3758/BF03211543
Unsworth, N., \& Brewer, G. A. (2010). Individual differences in false recall: A latent variable analysis. Journal of Memory and Language, 62, 19-34. doi:10.1016/j.jml.2009.08.002

Watson, J. M., Bunting, M. F., Poole, B. J., \& Conway, A. R. A. (2005). Individual differences in susceptibility to false memory in the Deese-Roediger-McDermott paradigm. Journal of Experimental Psychology: Learning, Memory, and Cognition, 31, 76-85. doi:10. 1037/0278-7393.31.1.76

Watson, J. M., McDermott, K. B., \& Balota, D. A. (2004). Attempting to avoid false memories in the Deese/Roediger-McDermott paradigm: Assessing the combined influence of practice and warnings in young and old adults. Memory \& Cognition, 32, 135-141. doi:10.3758/ BF03195826

Westerberg, C. E., \& Marsolek, C. J. (2006). Do instructional warnings reduce false recognition? Applied Cognitive Psychology, 20, 97 114. doi: $10.1002 / \mathrm{acp} .1170$

Wiese, H., \& Daum, I. (2006). Frontal positivity discriminates true from false recognition. Brain Research, 1075, 183-192. doi:10.1016/j. brainres.2005.12.117

Zhu, B., Chen, C., Loftus, E. F., Lin, C., He, Q., Chen, C., . . Dong, Q. (2010). Individual differences in false memory from misinformation: Personality characteristics and their interactions with cognitive abilities. Personality and Individual Differences, 48, 889-894. doi: 10.1016/j.paid.2010.02.016 